Portland State University

PDXScholar

Fall 2020

\title{
Greening Inequality: How Urban Sustainable Development Fails Under Neoliberalism
}

Josie R. Allison

Portland State University

Follow this and additional works at: https://pdxscholar.library.pdx.edu/honorstheses

Part of the Political Economy Commons, and the Social Justice Commons Let us know how access to this document benefits you.

\section{Recommended Citation}

Allison, Josie R., "Greening Inequality: How Urban Sustainable Development Fails Under Neoliberalism" (2020). University Honors Theses. Paper 954.

https://doi.org/10.15760/honors.977

This Thesis is brought to you for free and open access. It has been accepted for inclusion in University Honors Theses by an authorized administrator of PDXScholar. Please contact us if we can make this document more accessible: pdxscholar@pdx.edu. 
Greening Inequality:

How Urban Sustainable Development Fails Under Neoliberalism

\author{
By \\ Josie Allison
}

An undergraduate thesis submitted in partial fulfillment of the requirements for the degree of

Bachelor of Science

in

University Honors

and

International and Global Studies

\author{
Thesis Advisor \\ Professor Federico Pérez \\ Portland State University
}




\section{Introduction}

Sustainability is an increasingly pervasive topic amidst the surging population, accelerating urbanism, mounting ecological degradation, and intensifying climate change. It has become a buzzword for politicians, media, and corporations. Marketing teams target the environmentalist consumer with slogans and designs that align with sustainable sensibilities. It

has become a trend, a lifestyle, and a brand that characterizes an eco-conscious class. Capitalism has absorbed sustainability as a mode of elite, progressive consumerism that pays higher prices for organic, 'green', recycled, biodegradable goods. The message of ecological restoration has been lost in the culture of capitalism. The same reductionist mode of sustainability is failing in global cities. As globalism, urban migration, and neoliberalism continues to rise, cities are in competition with each other. Many have adopted the environmentalist brand, touting green infrastructure, sustainable lifestyles, and progressive policies to appeal to the eco-conscious elite.

Despite its banner of common-good altruism, urban sustainable development becomes a branding scheme for municipalities when it operates under and prioritizes a neoliberal agenda. Neoliberalism is the dominant economic philosophy within the United States, and other western economies, that emphasizes extreme economic liberalism and open markets with public fiscal austerity and the diminished role of governments. This has transferred a great portion of power and funding once held by the public sector into the hands of the private sector. Under neoliberalism, city governments function with stripped federal funding and limited budgets, while leaning on private companies for public operations, like urban development. When private interests are deeply embedded in urban development, urban landscapes become molded by profit and investment. 
Areas become developed and valued based on monetary gains rather than social needs. This has created drastic spatial inequality and gentrification in many cities. When this form of neoliberal development is tied to sustainability and environmental health, not only does spatialized economic disparity unfold, but environmental disparity unfolds as well. Green infrastructure, like bike lanes, parks and gardens, or street trees, are predominantly visible in high-income neighborhoods, or neighborhoods that are gentrifying. Low-income or minority spaces often lack these environmental amenities. Conversely, environmental burden and hazards are often zoned in close proximity to marginalized communities. This disproportionate exposure to pollutants and hazards and the uneven distribution of environmental 'goods' and 'bads' has been coined "environmental racism."

When the allocation of sustainable development is based on profit, sustainability becomes a pawn for neoliberal capitalism. Cities and developers co-opt sustainability as a marketing tactic to create a brand green, progressive urbanism. Attract environmental amenities pull the attention of media and investors who applaud an eco-friendly agenda, while overlooking the insidious byproducts that neoliberal sustainability produces. Urban sustainable development under neoliberalism generates gentrification and environmental racism. The failure of sustainable development to uplift underserved communities, and the concentration of hazards around these communities, undermines the legitimacy of urban sustainability.

The following pages will explore the failure of urban sustainable development, and the cyclical byproducts of green gentrification and environmental racism. I will specifically explore how this phenomena have unfolded in Portland, Oregon. Portland is renowned for its progressive, environmentalist urban planning, policy and infrastructure. It was one of the first municipalities to adopt the sustainable brand. However, it's reputation as a green city is 
paralleled by its reputation as an overwhelmingly White city. The history of racism and sustainable development in Portland paints an image of segregation, negligence, and spatial sacrifice. The largest district in the city, known as East Portland, is hardly recognizable as the community-centric, livable, green Portland that comes to mind. Portland's branding has successfully shrouded a large portion of its population and land in a green veil.

The thesis is interdisciplinary and draws upon the fields of urban geography, urban studies, and political economy. It is divided into two sections. Part one discusses the historical and theoretical context for the topic. I provide a brief summary of the history of sustainable development and describe the three pillars of sustainable development: environmental protection, economic growth, and social equity. I then explore the history of urban sustainable development and the transformations in urbanism that popularized urban sustainable development. I show how the rise of sustainable development paralleled the rise of neoliberalism, and how both share the logic of capitalist growth. I demonstrate how neoliberal economics monetized sustainability as a brand and privatized sustainable development in cities. Finally, I examine the history of green gentrification and environmental racism and discuss how sustainable development reinforces these unjust processes.

Part two specifically examines Portland, Oregon. I discuss Portland's history with urbanism and development and indicate that it differed from the rest of the U.S. in it's early adoption of an environmentalist agenda. I unravel the city's racist past and show how discriminatory housing practices racialized the urban landscape. The economic and racial geography of Portland overtime demonstrates profit-based development and neglect. I explore the record and impacts of Portland's development agency, the Portland Development Commission, now known as Prosper Portland. I then discuss the economic mechanisms that the 
city uses to fund development projects. Ultimately, I highlight how, despite its globally recognized brand as a progressive, sustainable, healthy city, Portland is starkly unequal. East Portland absorbs the city's pollution, poverty, and blight while it receives the least amount of funding than any other district. It has very few parks or greenspaces, significantly less tree cover, with auto-centric infrastructure that endangers pedestrians and bikers while producing pollutants and heat. 


\section{- PART ONE - \\ History, Terms, \& Context}

\section{The History of Urban Sustainable Development SUSTAINABLE DEVELOPMENT}

Urban sustainability is rooted in the history of sustainable development. Before the 1980s, 'development' referred to economic development programs installed in 'third world' countries after World War II. These programs industrialized the global south and encouraged ecologically harmful practices like monocrop agriculture, mechanized farming, the widespread use of pesticides and chemical fertilizers, and deforestation (Checker et al., 2015). Third world nations were simultaneously injected with a neoliberal economic agenda that emphasized privatization, small government and fiscal austerity, while bolstering free trade through deregulation and open markets. Through economic development programs, neoliberalism began to popularize and expand to global scale. These programs ultimately failed. They proliferated socially and environmentally exploitative agendas that filled the pockets of corporations and governments in the global north, while entrenching the global south in debt and ecological degradation (Gould \& Lewis, 2017).

As the spread of poverty and resource depletion became abundantly clear, the UN sought to mitigate these externalities by promoting a new form of sustainable development. The Brundtland Report, written in 1987 by the World Commission of Environment and Development (1987), states, "A world in which poverty and inequality are endemic will always be prone to ecological and other crises. Sustainable development meets the needs of the present without 
compromising the ability of future generations to meet their own needs" (p. 8). Sustainable development encompasses three pillars: environmental protection, economic growth, and social equity. The Brundtland Report outwardly names the alleviation of inequality as a central goal of sustainable development initiatives.

While these stated intentions seem ethical and benevolent, their lived impacts are much less virtuous. When sustainability operates within and perpetuates a neoliberal system where capital gains reign, the economic pillar becomes the primary goal. Checker et al. (2015) indicate that the rise of sustainability coincided with the rise of neoliberalism, producing a new economic and political arrangement that remains dominant in today's global order. Neoliberal ideology holds total faith in economic liberalism, claiming the unhindered market will "lift all boats" and that the role of the government should be quelled to empower and protect the private sector. Despite the guise of environmentalist morality, sustainable development aligns itself with neoliberal logic that claims the market economy will resolve those ecological and social problems addressed in the Brundtland Report.

Popular narrative around sustainability corresponds with neoliberal ideals emphasizing technological innovation and economic growth as fixes to environmental problems and social fragmentations. This logic ignores that ever-expanding production and capital plays a heavy hand in these problems in the first place. Capitalist solutions are instead framed as indisputably rational and apolitical, promoting the narrative that they are received with universal approval. Stakeholders are able to bypass any meaningful equity initiatives, while ignoring the ensuing inequality fomented by sustainable development (Gould \& Lewis, 2017). 


\section{URBAN SUSTAINABLE DEVELOPMENT}

The ethos of sustainability and sustainable development grew especially popular in urban spaces that suffered after post-industrialism and the rise of suburbia. Urban sustainable development corresponded to sustainable development on a global scale as a reactive push-back against post-WWII social arrangements and infrastructure. After WWII, the inner city saw mass unemployment and decay, as the decline of the manufacturing boom was met with veterans returning home in search of work. As demand for jobs and space grew within the devalued and dense environments of post-industrial cities, government spending redirected capital towards the urban periphery, where single-family housing developments and subsidized highways were assembling the American suburbs (Goodling et al., 2015).

Washington bolstered suburban development and homeownership through subsidies for large-scale construction, and mortgage loans and safety nets for lenders and borrowers. The expansion of infrastructure in the margins of cities paved the exit out of the inner city. The suburban population consisted mostly of those privileged White, middle- or upper-class families who could afford to move, leaving the working class and communities of color behind in the urban blight (Goodling et al., 2015).

With suburbia came sprawl, auto-dependency, and homogeneity. Open, natural space was consumed by housing and transportation infrastructure. Suburbanites found themselves caught in traffic and long commutes, as auto emissions caused habitat destruction and poor air quality. The suburbs were "socially deadening," and racially, culturally, and economically homogeneous and exclusive (Hagerman, 2007). By the 1990s, it was apparent to many critics that suburbanization was spurring social polarization and exacerbating environmental degradation. 
As infrastructure and capital were expanding in the outskirts of the city, the inner city saw the collapse of its own economy and built environment. The White, affluent families left with their wallets and taxes, leaving municipalities stripped of their tax base and burdened with debt. This financial strife was mirrored by national debt and inflation, culminating in the property and financial market collapse in 1973. Because high government expenditure and welfare economics doled out housing loans to build the failing suburbs, neoliberal economists pointed their finger at government intervention as cause for collapse (Goodling et al., 2015).

Sustainable development and neoliberalism stepped in to address the market collapse and urban decay that had unraveled American society. The collapse justified a neoliberal injection into the economy, demanding privatization and diminishing the power and budgets of local authorities (Gooding et al., 2015). Meanwhile, new forms of urbanism rejected suburbanization. Public concern for the environment and climate change grew, and the harmful impacts of suburban lifestyles became stark. Urban planners and scholars examined urban arrangements that would counter the loss of sociability and collapse of inner-cities caused by suburban development. Concepts of 'liveability' began to shape new, sustainable planning' . 'Liveable' planning retreated from auto-centrism, emphasizing public transit and biking infrastructure. Focus on urban density opposed suburban sprawl and encouraged walkability. "Sprawl became a foil for liveability. A liveable community, then, is one that does not sprawl-it has a distinct

\footnotetext{
${ }^{1}$ Hagerman (2007) defines liveability as "a vision for the future of the city that negotiates anxieties about the environmental damage and social fragmentation that occurred as a consequence of industrial modernism" (p. 288). Liveability is not a reversal of modernism, but instead aims to amend the damaging aspects and social fragmentation associated with it. When urban redevelopment of an industrial or blighted space focuses on liveability, it requires the suppression of those narratives, activities, and populations that reflect this contentious past. Liveable planning envisions a return of greenspace and environmental amenities, with walkable, narrow streets and decreased car dependency with older modes of transportation, like street cars. Liveability is an artifact of post-modernism and sustainable urban development (Hagerman, 2007).
} 
center, coordinates land use and transportation, is socially inclusive and focuses on environmental preservation" (Hagerman, 2007, p. 288).

Neoliberal economics coalesced with society's disenchantment with suburbia, prompting the return of capital to inner urban spaces. Municipal governments were recovering from their industrial decline and loss of tax base, while coping with neoliberal policies that stripped the welfare state and left them strapped for cash. In an effort to attract capital investment and remain financially solvent under neoliberalism, cities relied on amenity-based development and realestate to generate municipal-scale revenue (Gooding et al., 2015). Devalued post-industrial spaces became opportunities for investment. Cities' industrial pasts were co-opted and overridden by a new form of urbanism that targeted the "knowledge economy" or the "creative classes" that would return from their depreciating suburban retreats (Hagerman, 2007).

'Green' infrastructural development and amenities became markers for sustainabilityoriented cities that aimed to market themselves to an educated, affluent class. Neoliberalism coopted ecological sensibilities as a branding opportunity. Checker et al. (2015) indicate, "As public concerns about global climate change and urbanization grew, neoliberal agendas adopted sustainability as a popular discourse that simultaneously signaled environmental concern and progressive and participatory governance. As a brand, it especially appealed to the upscale, cosmopolitan, and politically liberal urbanites that cities hoped to attract" (p. 8). Ecologicallyminded projects began emerging in urban planning in the 1990s. Green infrastructure, such as urban gardens, parks and green space, and bike lanes, was used to aestheticize degraded postindustrial lots and bolster cities' reputations. 


\section{Sustainable Development in the Post-modern Global City}

\section{BRANDING \& PUBLIC-PRIVATE PARTNERSHIPS}

Urban branding aims to shape the reputation of cities and neighborhoods to ensure they are associated with positive, trendy identities and connotations. The goal is to attract targeted demographics, yield investments, and promote specific behaviors and interactions. This is done by accentuating and promoting selected characteristics, while subduing others (Vanolo, 2017). Place branding is a direct byproduct of neoliberal economics. Municipal governments seek to solidify a competitive edge in the ranks of global cities by prioritizing grandiose projects that attract global capital and shape a global imaginary, while failing to meet citizens basic needs (Checker, 2011).

Solidifying a renowned urban brand is increasingly important under pervasive neoliberalism and accelerating globalization and urbanism. Major cities face the dual pressures of neoliberal capitalism, demanding perpetual capital growth, and globalization, producing constant change with new markets and global trends. Neoliberal competition between cities compounded with urban migration increases the stress on municipal governments to attract highincome populations through branding. Cities must sell their brand to investors, tourists, affluent residents, and urbanists to grow investment and tax base (Gould \& Lewis, 2017).

As public concern about climate change and environmentalism has grown, sustainability has become an increasingly popular selling point. The marketing tactic known as "greenwashing" is now commonly implemented to persuade consumers that an organization is eco-conscious, and that their purchase will be virtuous. Performative environmental slogans or policies decorate products with terms like "eco-friendly" or "green," and statements suggesting that consumerism will plant trees in the Amazon. "From hybrid cars to organic vegetables to 
'clean' dishwashing detergent, being eco-friendly came to mean having enough disposable income to buy more expensive products branded as 'green"' (Checker, 2011, p. 22).

Similarly, cities adopt an environmental brand in hopes of attracting progressive, ecoconscious, spending populations. Large-scale development of environmental amenities and infrastructure become green landmarks for a city's image, contributing to its packaging as a "sustainable city." Lofty greening projects earn a city media attention, green awards, or a spot on one of the many touristic lists citing "The World's Most Sustainable Cities" (Checker et al., 2015) Under tight budgets enforced by neoliberal economics, municipal governments rely even more on private investments, thereby accentuating the importance of the urban brand.

Municipalities face privatization and austerity budgets that force them to relinquish public control over urban development trajectories to private capital in order to fund projects. Development projects are now often operated by public-private partnerships. Public-private partnerships involve the collaboration between government and private corporations to finance a project. Private actors typically benefit from tax breaks, liability protection, or partial ownership rights over public property or services in exchange for financial support. Different programs stimulating investment in underserved areas, like the New Markets Tax Credits, the Brownfields Incentives Programs, or the latest and greatest Federal Opportunity Zones, behave more like capital growth schemes and tax breaks than honest efforts to alleviate spatial poverty (Carter, 2019).

Public-private partnerships now dominate in a system that privatized the public sector. This means that private corporations and developers dictate the distributions of scarce resources and funding according to which "sustainable" projects promise the most return for investors. Elites direct where and when sustainable development is constructed, who it is for, and how it is 
used. Private donors fund parks and environmental amenities that personally serve their interests through private-public partnerships that encourage this process (Gould \& Lewis, 2017). Certain public goods and spaces, often those with cheap land inhabited by low-income populations are identified as investment opportunities and are developed, or redeveloped through private funding. Outside investors see opportunity in cheap land and help finance state-led development of a public amenity. Often development plans that rely partially on private capital concede to private needs. Investors will ask that luxury apartments or other elite amenities are included in the plans. This means that funding for sustainable development or environmental amenities will also construct exclusionary infrastructure for the anticipated higher-income populations. Ultimately, the development of a supposedly public amenity may price out the incumbent lowincome communities as higher-income residents move in. This allows privileged, exclusive communities to "capture public goods for themselves" (Gould \& Lewis, 2017, p. 154). Neglected, low-income spaces are either bypassed or gentrified.

The failure to produce social equity through sustainable development projects is due to the prioritization of capital gains over community well-being. When urban sustainability functions within, and fuels, a neoliberal economy, wherein capitalist agendas remain dominant, environmentalist initiatives often become centered more on financial gains than ecological and social health. Sustainability becomes a branding tactic. Cities broadcast their sustainable development efforts in order to shape their brand as an environmentalist municipality. Sustainable policies and projects project an image of a progressive, eco-conscious agenda that may appeal to a desirable, high-income class. Lower-income populations and communities of color are not lucrative consumers or tax payers and are thus less promising for investment. 
Examining the unequal distribution of environmental amenities in cities highlights the social disparity in sustainable development.

\section{GREEN GENTRIFICATION \& ENVIRONMENTAL INJUSTICE}

This all culminates in the darkest underbelly of sustainable development, 'green gentrification' and environmental injustice. Although greening initiatives improve the environmental and economic conditions of urban spaces, they disproportionately impact different communities and exacerbate inequality. This undermines the legitimacy of urban sustainable development by failing to fulfill the crucial pillar of social equity.

Gould \& Lewis (2017) coined the term 'green gentrification' as the process of gentrification that follows sustainable development initiatives. "Characterized by investment in historically disinvested urban areas, gentrification is often realized through an influx of young, educated, artistic, or 'creative class' individuals seeking low rent and exciting cultural environments. This first wave of community change is followed by further investment as the area is recognized as up-and-coming" (Flanagan et al., 2016). Disinvested neighborhoods are opportune for renewal and a new creative class due to cheap land and social heterogeneity. In order for new capital to enter the area, the incumbent population and culture must be uprooted. New development is rarely intended to uplift the existing residents, but aims to attract an earning population, prioritizing economic gains over human livelihood.

The development of green infrastructure often spurs a form of gentrification that ultimately excludes the pre-existing populations from sustainable development. As environmental amenities are created or restored, property values and prices start rising as 
wealthier populations are attracted to the area. This effectively prices out incumbent residents, paving way for a new earning class to enjoy the freshly revitalized sustainability. As vulnerable communities are displaced and removed from the renovated environmental amenities, they are pushed into affordable, low-income areas. These 'landing zones,' where displaced populations migrate to, are often in the peripheries of cities, where cheap, devalued suburban housing or hazardous industrial zones are located.

The result is spatialized inequality and uneven development throughout the urban landscape. Due to gentrification and housing segregation, political power is concentrated in specific neighborhoods, while the political voices of lower-class and minority communities are disempowered. Populations with the political and economic power can dictate where they want to live and what they want their neighborhood to look like. They can move towards clean areas with environmental amenities, and, conversely, obstruct any planning intending to encroach on their space with industrial blight. Meanwhile, systemic exclusion from systems of capital accumulation limits vulnerable communities' power within a neoliberal society that conflates capital power with political power.

Ultimately this produces spatially distributed power and poverty, with some neighborhoods lacking the capacity to mobilize against the zoning of environmental burdens and health threats, or to demand that their environmental amenities are revitalized (Gould \& Lewis, 2017). Environmental burdens, such as pollutants, Locally Unwanted Land Uses (LULUs), and the associated health risks are inequitably concentrated around disempowered minority or lowincome populations (Gould \& Lewis, 2017; Commission for Racial Justice, 1987; Hurley, 1995). The concentration of power in certain neighborhoods exacerbates private-public partnerships' elite zoning practices that select disempowered neighborhoods, typically low-income 
communities of color, to site LULUs because they are least likely to incite weighty political resistance (Bergman, 2017). These communities thus bear the burdens of environmental hazards. "Policymakers have an incentive to retain the important functions that environmentally degraded neighborhoods play in the greater metropolis as spaces to which the environmental risks that are unwanted by wealthier communities may be distributed" (Gould \& Lewis, 2017, p. 32).

The term 'environmental racism' specifically describes the "race-based discrimination in the siting of hazardous facilities and the remediation of environmental hazards in the United States" (Gould \& Lewis, 2017, p. 26). Studies indicate that race is a strong indicator for the zoning of environmental hazards. In 1987, the United Church of Christ's Commission for Racial Justice exposed this phenomenon in a study that examined racial minorities' rate of exposure to both commercial and uncontrolled hazardous waste facilities. Their findings reveal an indisputable pattern of communities with higher numbers of waste sites containing the highest percentages of racial and ethnic minorities. Three out of five of the nation's largest commercial waste sites at the time, which constituted $40 \%$ of the country's landfill capacity, were operated in predominantly Black or Hispanic communities (Commission For Racial Justice, 1987).

People of color face limitations in the housing market due to combined forces of racial discrimination in lending, and real estate practices which associate whiteness with profitability. Lending discrimination racialized access to credit for mortgages and home improvement loans, and redlining non-White neighborhoods restricted the housing stock for people of color while allowing those neighborhoods to accumulate decay and toxins (Gould \& Lewis, 2017). Poor and working-class populations suffer under an economic system which hinders their mobility and capacity to avoid exposure to environmental hazards, either at work or in their neighborhoods. Poor people of color experience racial discrimination and economic exclusion, producing 
intersectional disempowerment that is aggravated by environmental injustice. They experience both forms of economic and racialized restrictions, and thereby have the most limited capacity to escape pollutants and environmental hazards (Gould \& Lewis, 2017).

In February of 2018, the Environmental Protection Agency (EPA) confirmed that environmental racism has continued to threaten marginalized communities with a study that indicated impoverished and non-White communities in the United States are significantly more likely to breath and live in polluted air (Newkirk II, 2018). In Louisiana, an 85-mile corridor between Baton Rouge and New Orleans, that hosts over 150 oil plants and refineries and a majority Black population, has been coined "Cancer Alley" due to the alarmingly high rates of death and illness from carcinogen exposure (Lee, 2015). The majority Black and Hispanic residents of Pahokee, Florida confront decades of pollution from the "Big Sugar" industry, which has contaminated nearby Lake Okeechobee with hypertoxic algae, endangered the drinking water, and undercut property values (Bergman, 2019). Toxic coal ash endangers the lives of the 1.5 million people of color living within the catchment areas of the nations' 277 power plants (Bienkowski, 2016). Around 70\% of EPA's contaminated waste sites are located near lowincome housing, and an estimated 2 million people, predominantly from communities of color, live within a mile of one of the 327 Superfund sites prone to climate-change-related flooding (Bergman, 2019).

Urban sustainable development contributes to unjust capitalist systems that produce the insidious, dual byproducts of green gentrification and environmental racism. Green gentrification is the latest form of this capitalistic displacement. The post-industrial inner city offers swaths of available, low-cost land that can be repurposed with modern environmental amenities. As industrial lots become urban parks or new LEED certified luxury complexes, the industrial, 
working-class history of these spaces is glossed over or co-opted as an aesthetic (Hagerman, 2007). Gould and Lewis (2017) note that, "Urban greening is being pursued by global cities in a neoliberal era in which both sustainability and gentrification are viewed as urban regeneration and growth strategies" (p. 166). This excuses the displacement and inequity that unfolds as a result of sustainable development in cities.

Underserved communities of color and low-income residents are continually displaced as new environmental amenities enter their neighborhoods, forcing them to migrate to areas without such amenities where property values are lower. Urban sustainability contributes to the phenomenon of environmental racism by excluding marginalized populations from clean and healthy spaces with green amenities (Checker, 2011)(Gould \& Lewis, 2017)(Hagerman, 2007). While these groups are pushed into environmentally burdened areas with LULUs or pollutants, White affluent residents avoid these hazardous areas and migrate to spaces where these amenities have been curated for them.

This creates what Gould and Lewis (2017) call an 'inverted quarantine.' Due to the neoliberal reallocation of control over development from municipal governments to private entities, public-private partnerships effectively create protective 'bubbles' from environmental harm for elites by constructing exclusionary green amenities in high-income or gentrifying areas. According to Gould and Lewis (2017), "The inverted quarantine is a private approach to environmental safety through the mechanism of purchasing insularity from generalized environmental harm (like paying for bottled water instead of publicly funding clean water supplies (see Flint, Michigan), or buying organic produce rather than mobilizing for regulation of pesticides)" (p. 154). Gould and Lewis (2017) assert that the inverted quarantine ensures 
environmental health and safety based on income, and encourages those with the most financial and, thus political, means to retreat from public policy and political mobilization.

Without equal distribution of environmental impacts, benefits, and hazards, those with the least capacity to affect change experience the greatest environmental degradation and harm. Meanwhile, affluent communities with capital power experience healthy and beautiful environments, flush with green amenities. When influential populations are insulated from hazards and the impacts of ecological degradation, there is a "severed feedback loop" in the social and natural systems, and meaningful progress in environmental policy remains stagnant. Therefore, an absence of social equity in urban sustainable development not only strips the project of its indispensable equality pillar, but cripples its environmental pillar as well. The inverted quarantine highlights how critical social equity is in sustainable development. Without it, environmentally rich and environmentally poor communities are formed, and the damage is exported to those that can't effectively contest (Gould \& Lewis, 2017).

\section{A VICIOUS CYCLE REPEATS ITSELF}

As the process of sustainable development and green gentrification repeats itself in cities, a vicious cycle of environmental inequality and spatialized racism molds the urban landscape. The use of green infrastructure as a branding scheme to promote a city's image of sustainability encourages the selective valuation and devaluation of certain areas according to what will generate financial prosperity. Rather than uplifting the environmental, economic, and social health of all citizens, sustainable development's central motives are to attract an eco-conscious, 
affluent class. Greening projects are used to promote the brand of sustainable lifestyles that appeal to these target groups (Gould \& Lewis, 2017).

When neoliberalism is embedded in sustainability, green gentrification and environmental racism are reproduced and justified by profit. The inequality produced by these insidious byproducts reinforces the inverted quarantine and exacerbates ecological and social regression. As green branding alters the landscapes and imaginaries of endowed neighborhoods, it substantially impacts the social and economic fabric of a city. Urban branding produces tangible consequences that inform policy, investments, consumer choices, and media coverage. When spaces are unevenly branded as sustainable or liveable, spatial inequality is reinforced (Vanolo, 2017). Parks, gardens and bike lanes beautify valued spaces and create an urban imaginary positively associated with healthy lifestyles and sustainability. This reaffirms the inverted quarantine which paints a positive picture of the environmental condition in the eyes of privileged populations who actually enjoy the amenities associated with a sustainable brand. Meanwhile, underserved spaces' negative imaginaries are reproduced and solidified by the concentration of poverty and environmental burdens. Blighted stigmas justify the continual neglect of devalued neighborhoods, and may attract environmentally hazardous zoning (Vanolo, 2017).

If sustainable development fails to uphold the pillar of social equity, it undermines the pillar of environmental protection. Without social equity in sustainability, environmental protection is only secured for privileged populations inside the inverted quarantine. This diminishes the capacity for meaningful environmental policy and protection because those populations with the most political and economic power to impact change are the least affected 
by hazards. Meanwhile, the marginalized low-income and minority communities who are the most exposed to ecological hazards have the least amount of power (Gould \& Lewis, 2017).

The more severe the economic and ecological rift in the urban landscape becomes, the more neoliberal logic steps in to solve the issue through production and sustainable development. This agenda disregards the fact that production is in large the cause of the damage in the first place. And so repeats a cycle of ever-expanding capital growth, inequality, and ecological degradation under the brand of sustainability. The failure of urban sustainable development and its malign impact on society is visible in cities throughout the globe. The trend of 'greening' initiatives is visible in New York, Chicago, Bogotá, Copenhagen, Berlin, Mexico City, Singapore, London, Barcelona, Sydney, and more. Each of them hope to land a spot in the ranks of the most attractive cities and enjoy the investment and economic growth that may follow.

The next section will examine this phenomenon in Portland, Oregon, a city notoriously recognized as a cosmopolitan center of progressive politics, creativity, and sustainability. Portland, Oregon is a textbook example of a city where green urban branding produces exclusionary environmentalism, privileged sustainable living, and environmental injustice. 


\title{
- PART TWO - \\ Portland, Oregon
}

\begin{abstract}
"We're not doing [sustainability] just to be altruistic. Part of the reason we're doing a lot of this: There's money to be made, to be crass. There are hundreds and hundreds of companies in Portland that are manufacturing or offering services that are sustainable technologies or products or services. They are selling them to the rest of the world now. And most of these things are things we want to do to create better, healthier places anyway - but by doing that, you create a place where people want to live and have businesses." (Smith, 2012)

Susan Anderson (Portland's Director of the Bureau of Planning and Sustainability)
\end{abstract}

Portland, Oregon is renowned for its sustainability and progressive politics. It has long been praised for abundant greenspace, impressive public transit system, progressive biking infrastructure, and generally eco-conscious culture. It is true that Portland was one of the municipal pioneers of urban sustainable development. In the 1970s Portland began reorienting city planning away from sprawl and started emphasizing urban densification. It's light rail system is used as a model for other cities. Portland's 'skinny streets' program promotes walkability and slower traffic as opposed to auto-centric roads (Damewood, 2015; TED, 2013). Most people's imaginary of Portland involves restaurants and breweries with organic menus, lots of trees and parks, and local boutiques all coexisting in intimate enclaves of urban life that more closely resemble small towns than major cities. While this is an accurate depiction and lived reality for some neighborhoods, many Portlanders experience a very different city. For those living in the margins of the city, these supposedly defining features of one of the most sustainable American cities are nowhere to be found. 
In the following section, I will explore how Portland, a pioneer of urban sustainable development and a globally recognized 'sustainable city,' has produced severe spatial inequality and environmental racism. This is largely due to the capitalist mindset and neoliberal economics locked into the city's development plans. Urban development in Portland historically correlates to racism, environmentalist branding, and profit. Portland has shaped its imaginary as a progressive, sustainable, creative city. It touts a culture of social equality and ecological awareness, but after exploring the margins of the city, it is easy to see that this is a facade.

Green infrastructure and Portland's archetypical features of walkable streets, clean and intimate neighborhood alcoves, and ample greenspace were developed over the top of workingclass, post-industrial neighborhoods. Portland's brand as a creative, eco-conscious city is conditional. Its development relies on cheap land and the subsequent displacement of incumbent, mostly low-come and non-White residents. Its success is measured by returns on investments, not quality of life. As discussed in the previous section, much of this failure is due to the steadfast marriage of sustainability to neoliberal capitalism. Despite Portland's early commitment to urban sustainability and its rejection of suburban sprawl before it was the status quo, Portland is not unique in the actual impacts of sustainable planning. Just like many other major cities across the globe that have now subscribed to the green brand, Portland's sustainable development has failed to achieve the crucial pillar of social equity (Gould \& Lewis, 2017).

The city's district east of the notoriously blighted $82^{\text {nd }}$ Ave., known as East Portland, exemplifies this failure well. While the rest of the city enjoys the markers of Portland's sustainable, progressive brand, East Portland sees sprawling concrete prone to heat islands, autocentric infrastructure that is dangerous for pedestrians and bikers, and significantly fewer parks and greenspace compared to its western counterparts. The spatialized sustainability and unequal 
development of Portland's urban landscape is residual from a history of racist housing practices, gentrification, and political neglect underlined by neoliberal economics which prioritize capital gains over community health.

Portland, Oregon's history with industrialism and subsequent new urbanism closely reflects most national trends, however the city differs with its early adoption of sustainable development and the 'green' brand. Understanding the historical context in which progressive policy and sustainable development occurs is crucial for analyzing the intention versus the impact of sustainability. A discussion of the city's history and relationship with industrialism and urban development will preclude the analysis of the city's current capital landscape. My research examines historical essays, and scholarly and journalistic articles through a socioeconomic lens in order to analyze the relationship between neoliberalism and sustainable development in Portland. I will specifically examine how the impacts of neoliberalism and spatialized development molded the Albina District, the waterfront, and the neighborhoods east of $82^{\text {nd }}$ Ave. 


\section{The History of Spatialized Inequality in Portland, Oregon INDUSTRIALISM \& SUBURBANIZATION}

As World War II accelerated industrialism in the inner-city, waves of labor migration washed into Portland and other northern cities to fill the growing demand for low-skill labor. Industrial production clustered around the waterfronts of the Willamette and Columbia rivers (Hagerman, 2007). Working-class residents employed at the plants populated the surrounding neighborhoods along the water and in north Portland. The city of Vanport was constructed in the North of Portland to house the mass influx of industrial workers. It became the United States' largest wartime housing development and Oregon's second largest city, with over 40,000 laborers and their families (Stroud, 1999). Incoming African American workers comprised much of the growing population, causing the Black population of Portland to spike from under 2,000 to over 20,000 by the end of the war (Goodling et al., 2015) A majority of the African Americans who migrated during this time lived in Vanport. In 1948, the cheaply-constructed city was destroyed in the Vanport Flood and its residents were left to find scarce housing elsewhere. Discriminatory neighborhood covenants forced Black residents to crowd into the dense and derelict Albina District (Stroud, 1999; Anderson, 2018). The Albina District in northeast Portland had long been a hub for Black residents in Portland because it was the only area in the city where they were free from housing discrimination (Habitat for Humanity, 2020).

The systemic concentration of immigrants and people of color to these neighborhoods justified the area's neglect because they were considered 'blighted' due to their racial composition (Stroud, 1999). The Portland Realty Board asserted that it was "unethical" for a real estate agent to sell property in a White neighborhood to Black or Chinese people, and this policy became institutionalized. Government subsidies were distributed accordingly, only investing in 
the development of parks, schools, and essential infrastructure in White neighborhoods (Gibson, 2007). Banks adopted the rule by assuring that any Black person seeking a housing loan was denied unless their mortgage was in the Albina District. Renters in the Albina District often faced higher rents and deposits from profiteering landlords (Habitat for Humanity, 2020).

As wartime capital from production waned after the war, real estate development and construction injected new capital into the margins of the city. Portland's suburbanization paralleled national trends throughout the 1960s. The wealthiest suburbanites moved to the western and southern margins of the city, while the majority of the middle- and lower- income residents, over twice as many, moved to the east. From 1945 through 1960, East Portland saw the infill of low-cost ranch-style tract housing. The population between $60^{\text {th }}$ and $148^{\text {th }}$ street increased by 30,000 residents (Goodling et al., 2015). Many of these residents continued to commute into the inner-city for work or social ties. Suburbia's traffic and overcrowded neighborhoods began to max out the city's infrastructural capacity, while draining the tax base.

Portland recognized the environmental damage and social fragmentation germinating from suburbanization. This disillusionment paralleled national trends. However, Portland rejected suburban growth and sprawl earlier than other cities, earning it widespread recognition as a sustainable city.

\section{THE FALL OF SUBURBIA \& THE RISE OF SUSTAINABLE DEVELOPMENT}

Taking the lead in the turn away from suburban sprawl, Portland adopted an environmental agenda early on and oriented city planning towards an urban 'sustainability fix'. In the 1970s, the environmentalist governor, Tom McCall, spearheaded preservationist policies 
like the bottle bill, the Willamette River cleanup, and environmentalist land-use planning. He established the Land Conservation and Development Commission in 1973, which observed the local adherence to newly developed land-use goals. Among these goals were urban growth boundaries, which confined urban sprawl by limiting development outside of defined parameters. The boundaries protected agricultural and forest industries that were being impeded upon by the growing urban sprawl. The growth boundaries protected the environments of middle and upperclass neighborhoods and the economy of the metropolitan center, while ensuring that intensive development was condensed in decidedly disposable areas outside these confines (Stroud, 1999). The growth boundaries and other conservationist initiatives earned Portland the early status as a progressive, eco-conscious city. Portland solidified its sustainable brand, which would harness investment capital and incoming affluent residents (Goodling et al, 2015).

This new 'sustainable' planning approach redirected capital flow inward, while growth management policies limited the flow of capital outwards. Inner-core neighborhoods saw private and public capital fund redevelopment projects that developed transit infrastructure, converted warehouses to lofts, and constructed LEED-certified luxury living units and retail spaces on vacant lots (Goodling et al., 2015). The most drastic transformations occurred in districts adjacent to the Willamette river, such as lower Albina on the eastside, and the River District and South Waterfront District on the west side (Gibson, 2007; Hagerman, 2007).

Hagerman's (2007) examination of industrial waterfront urban renewal through a political economic lens offers important insight on the impacts of redeveloping post-industrial spaces. Previously industrialized riverfronts are easy targets for sustainable development stakeholders. Cheap land along the water offers ample opportunity to revitalize the environment as a green amenity that raises the property value of the surrounding neighborhoods and attracts 
new capital. As nature is reintroduced and the space is rebranded with a modern, sustainable identity, necessary socio-economic transformations proceed that are spearheaded by powerful actors. The sustainable development of post-industrial waterfronts not only clears out the pollution and blight, but also paves over the legacy of social and ecological degradation. The historical conflict that once shaped this space, and the exploitation of its land and labor that was indispensable for the growth of the contemporary city, must be razed and replaced. Hagerman (2007) writes, "The development of waterfront and industrial districts involves a shifting of spatial priorities by urban governance regimes, from a history of containing the urban poor and industrial uses to dispersing them in favor of destination-oriented retail and residential areas imagined as post-industrial or 'creative' economic spaces” (p. 287).

Much of Portland's urban landscape was transformed by this sort of cultural and economic overhaul. The amenities that border the waterfront today, such as the expansive esplanades and well-kept parks, are products of a capitalist shift, from an industrial economy to a post-modern, creative economy. The working-class residents who once occupied these spaces were uprooted as developers and planners prioritized a new urban brand that departed from industrial production. The displacement that followed these projects pushed low-income residents and communities of color further to the margins of the city, particularly East Portland. Industrial zones adjacent to Portland's downtown weren't favorable to the city's sustainable urbanism and progressive policies (Hagerman, 2007; Goodling et al., 2015).

In 1972, the Downtown Plan marked the initial motion towards the reconstruction of the city center and the decaying industrial waterfront. The historic downtown parameters were extended through former industrial spaces and railyards. The city's quasi-independent development agency, then called the Portland Development Commission (PDC), announced that 
15,000 new units were to be constructed on the post-industrial land. The PDC deemed these two waterfront zones on opposite sides of the central downtown, known as the River District and the South Waterfront District, as underutilized, despite their occupation by many working-class and marginalized communities (Hagerman, 2007). The PDC fomented mass displacement and gentrification in the area. New businesses and professionals entered and thrived as people of color and lower-incomes were wiped out, along with their culture and historic role in the formation of Portland (Sevenko, 2017).

These waterfront districts, which once contained underutilized and abandoned buildings, deserted railroad yards, and swaths of industrial production sites, were 'revitalized' as a postmodern commercial and condominium district. The architectural and design elements of new buildings incorporate post-industrial accents that serve solely aesthetic purposes, without any historical context. Rather than offering homage to the displaced economies and working classes that once occupied and shaped these landscapes, these industrial relics are dislocated from their past and co-opted as charming, quirky design accents in chic apartment buildings or brew pubs (Hagerman, 2007).

The Albina District underwent a similar transformation. Before the 1990s, Albina had become a refuge for African American residents who faced severe housing discrimination in nearly every other neighborhood in the city. After the Vanport Flood, many displaced African Americans found themselves landing in the crowded district, further increasing the Black population. By 1960, over $80 \%$ of Portland's 18,000 Black residents lived in Albina (Aleck, 2017). The Albina District was a vibrant hub for working-class Black families, though the community suffered neglect from municipal investment and businesses struggled to get off the ground due to loan discrimination (Ackerman, 2016; Anderson, 2018; Gibson, 2007). 
Beginning in the 1950s, the PDC launched several development projects and selected the Albina District for zoning. Like the waterfront districts on the west side, Albina was characterized as blighted, and the PDC deemed clearance and redevelopment projects necessary to remove and contain such blight. The Memorial Coliseum, a large events and entertainment arena, was approved for construction in lower Albina in 1954. By the time it opened in 1960, 476 homes were demolished and over 3,000 people, most of whom were African American residents, were forcibly vacated (Anderson, 2018; Aleck, 2017). The subsequent construction of Interstate 5 and 99 continued this pattern. The PDC consistently selected Black, working-class neighborhoods to zone large-scale development projects. In the 1970s, the expansion of Emanuel Hospital was again sited in the lower Albina neighborhoods, destroying over 300 predominantly Black homes and businesses (Sevenko, 2017).

The construction of these new amenities significantly altered and degraded Albina's environment. The sprawling parking lots and massive buildings coupled with the loud, polluting highways contributed to plummeting property values and community health (Aleck, 2017). Most of the displaced Black residents were forced to remain in the Albina district due to persistent racist housing and lending practices. Many families relocated to the increasingly disinvested neighborhoods in northern Albina, where the residents faced predatory lending, negligent landlords, and speculators. Nonetheless, the Albina District remained the heart of Black livelihood in Portland (Gibson, 2007; Habitat for Humanity, 2020; Ackerman, 2016).

In the 1990s, the city worked with the PDC to launch urban renewal projects that ultimately gentrified the area and uprooted the Black community almost entirely. The City adopted the Albina Community Plan in 1991, aiming to aestheticize and revitalize the district. (Anderson, 2018). Many of its thousands of vacant lots were developed and loans were dished 
out to improve the storefronts of several businesses along historic corridors. A light-rail was developed along Interstate Ave. in 2004, connecting Albina to downtown. Developers and real estate companies capitalized on Albina's old Victorian housing stock and central location, marketing homes as quaint and historic, while renovating them to hike up their price. As old houses were modernized and in-fill construction brought new apartments and commercial spaces, property values skyrocketed, leaving most of the incumbent African American population to pack up and find cheaper housing elsewhere. In some cases, entire housing complexes were evicted to pave way for new improvements and incoming tenants. Neighborhoods in Albina saw their housing prices double and even triple in several cases (Gibson, 2004; Goodling et al., 2015).

Aside from the financially-driven displacement, Albina underwent extreme cultural displacement as well. Despite implications that the new development would serve the community health and livelihoods of the longtime African American population, the yoga studios, bike shops, brew pubs and coffee shops popping up along the historically Black Albina welcomed incoming White affluence. New development signaled eco-conscious virtues to these new White residents, with condominium complexes flashing names like "Eco Flats PDX," advertising "Sustainable urban living." Meanwhile, Black businesses and residents were forced to close and move out. Many of the displaced residents found cheap housing stock in the eastern margins of Portland, in an area now notoriously underserved in the city known as East of $82^{\text {nd }}$. (Goodling et al., 2015).

Goodling et al., (2015) note that "The sustainability fix in Portland is very much a spatial one; as capital returned to inner Portland under the banner of sustainability, liveability, and neighborhood revitalization, devaluation of East Portland's built environment ensued - even as 
population increased" (p. 14). Portland touts its sustainability brand, with corresponding urban planning that encourages density, walkable neighborhoods, and small streets. However, these development plans only reached the city's inner-core and the affluent populations for whom this form of sustainable consumerism and eco-conscious living is marketed. The lower Albina District and the riverfront districts offered ample, low-cost space from Portland's industrial past to be cheaply co-opted and renovated into environmental or infrastructural amenities that would garner investment and attract capital. The absence of political and capital power within the incumbent low-income and minority communities paved a smooth road for the PDC and planners to uproot these populations and replace them with a more lucrative group. The displaced group often landed in East Portland, where none of these sustainable development projects or infrastructural renovations were underway. The unevenness of Portland's sustainability allows for extreme spatial inequality which effectively undermines the city's third pillar of social equity. As a city that prides itself as a progressive center for social and environmental justice, these failures highlight the limitations of Portland's brand. East of $82^{\text {nd }}$ has become the dumping zone for the city's burdens to keep them out of sight and out of mind, and to maintain the crisp image of its sustainability brand. While the inner-core sees rising incomes, green amenities, and increasing whiteness, East Portland accumulates the bulk of the city's poverty, environmental hazards, and marginalized populations. 


\section{Sustainability Under Neoliberalism in Portland, Oregon DISPROPORTIONATE DISTRIBUTION OF GREEN AMENITIES}

Sustainable development in Portland has provided green amenities for select populations and inner-core spaces, but more significantly, it has secured for Portland a reputable sustainable brand. Portland's renowned reputation as a sustainable city puts it on the proverbial map for investment and affluent migration. The inverted quarantine (Gould \& Lewis, 2017) and its branding have created a green guise of environmental health and community prosperity that shapes a positive imaginary of Portland. Businesses looking to tap into the green economy, or affluent populations seeking a healthy, green urban lifestyle find a promising portrait of shiny sustainability in Portland, Oregon. In this way, the virtue of sustainability is much more of a marketing tactic than a means of uplifting the environmental, social, and economic conditions of its existing communities. Development meant to improve environmental health and community livelihood is predominantly constructed in and for higher-income populations, primarily because they are a more lucrative consumer group. East Portland and other poor, diverse communities have become sacrificial spaces of aggregate pollution, poverty, industry, and municipal negligence. These spaces and people fill the essential role of absorbing the urban burdens and environmental hazards that pose threats to capital and the pristine sustainable imaginary inside the inverted quarantine (Hagerman, 2005).

Often the sustainability brand is implemented to secure investments that fund greater development projects which may not be associated with an environmentalist agenda. The city and development agencies engage with citizen's eco-conscious virtues by highlighting select environmental features of a project, while brushing over the rest of the plans that may entail apartment construction, parking lots, or commercial space. It is useful for these development 
projects to be zoned in higher-income neighborhoods with higher tax bases and more disposable income to invest in their community development.

For example, the development of Portland's waterfront districts incorporated several new parks to revitalize the post-industrial sites into environmental amenities. Planning for public parks typically promotes civic engagement and centers the narrative around liveability, nature and ecological restoration, and sociability. City documents, media, and developers disseminate imaginaries that strategically appeal to environmentalist sensibilities to build support for the development project. Public planning events and the promotion of community input create a veneer of public inclusivity, but ultimately the final decision making occurs behind closed doors and the final landscape often looks significantly different than the designs portrayed and discussed during public discussions (Hagerman, 2007).

The restoration of the South Waterfront District focused on reengineering the riverbanks in order to restore their ecology and revitalize the salmon habitat in the river. Environmentalism and salmon restoration were publicly broadcasted to mold the imaginaries of the future park, and to soften, or quell, criticisms about the other aspects of the development. In reality, public money for this project was used to garner a much greater sum of private investment through development that served elite property owners and the real estate industry that would eventually fund the public park. "In exchange for infrastructure spending and development bonuses provided to property owners and developers, the public was to receive new ecological spaces that would return salmon to the river and people to the district that it bordered" (Hagerman, 2007, p. 293). The public-facing focus on sustainable development and environmentalism was used to justify public spending, while obscuring the fact that the majority of the funding was used for elite residential housing stock. 
Hagerman (2007) asserts that "Wealthy in-migrants become the focus of liveability discourses as they hold the key to fulfilling the urban renewal district's self-fulfilling objective of increasing the property-tax increment, to generate the public sector investment capital that is needed to galvanize the next round of public infrastructure improvements" (p. 293). Expansive environmentalist projects are presented to the public to attract investment, and to get approval from the city. Ultimately, however, many of the touted design features don't come to fruition, are deprioritized behind the development of commercial and luxury infill, or are significantly altered in their final production due to budget limitations.

The role of sustainability becomes a marketing gambit that distracts from the failures of the city and developers to instill true sustainable development that upholds each pillar of economic, environmental, and social equity. The ultimate goal is not to ensure ecological and social health of Portland's land and people, or if it is, this intention is suppressed. It seems instead that the goal is to secure capital expansion, and that the force that drives sustainable development is not an environmental altruism, but neoliberal capitalism. Susan Anderson, Portland's Director of the Bureau of Planning and Sustainability, even stated in an interview, 'But we're not doing [sustainability] just to be altruistic. Part of the reason we're doing a lot of this: There's money to be made" (Smith, 2012). If the focus is on making money, it is only logical that the developers and city planners would overlook the chronically disinvested neighborhoods in the margins of the city.

The renovation of post-industrial landscapes provides the opportunity to pave over ecological damage, while installing in its place new urbanism and lifestyles that appeal to the young, educated, creative class. These wealthy residents adhere to and consequentially manifest the brand of Portland, and other sustainable cities, by engaging in creative industries, local 
consumption, and environmentalist economies. Redevelopment projects and the markers of community health, localism, and sustainability that shape Portland's brand are only visible in areas that are tailored to this spending class. These redevelopment projects often include green infrastructure that hold massive benefits for the health and communities of surrounding neighborhoods. Conflating these features, like bike lanes, pedestrian-friendly streets, parks, or street trees, with profit and higher incomes produces spatial inequality. The lack of these amenities in low-income, minority neighborhoods contributes to issues with social, bodily, and mental health. Portland's distribution of biking infrastructure highlights this.

Portland is celebrated for its biking culture, and is often listed as one of the most bikefriendly cities, but robust biking infrastructure is only enjoyed in the inner-core of the city. Flanagan et al. (2016) examined the distribution of biking infrastructure throughout neighborhoods of different incomes in Portland and Chicago. Their research indicates that investment in cycling drops off in minority-dominant or low-income neighborhoods, most of which are in East Portland. However, this is not the case for neighborhoods experiencing an influx of wealthier in-migrants and rising property values, otherwise known as gentrification (Flanagan et al., 2016).

There are two different 'classes' of cyclists; those who bike out of necessity because they can't afford a vehicle or transit, and those who bike as a lifestyle choice. The latter group, the eco-conscious class, attracts and enjoys higher investments in safe and pleasant biking infrastructure. Cycling is another means through which municipal governments and developers brand their cities as sustainable, community-oriented, and progressive. It is associated with liveability and healthy communities, but is not achieved in underserved areas that aren't undergoing patterns of gentrification and capital growth. Lack of economic and political power 
inside these neighborhoods make it extremely difficult to sink any funding for safer transportation infrastructure without an encroaching gentrifying class (Mirk, 2009; Flanagan et al., 2016)

For example, the Portland Bureau of Transportation sought to redesign the major biking commute corridor along North Williams Ave. to improve the bike lanes and increase safety. North Williams is in the Albina District, and was once a hub for Portland's African American community and culture before waves of gentrification transformed the neighborhood. At a public forum discussing plans for the project, long-time, Black residents voiced their dismay at the neglect they experienced until White affluence entered the area. One resident lamented, "'You say you want it 'safe' for everybody, how come it wasn't safe 10 years ago?'” (Flanagan et al., 2016, p. 124) While the city of Portland was promoting an altruistic narrative centered on public safety and environmentalism, the incumbent Black community expressed the project's dark underbelly. Black residents voiced the pervasive neglect, displacement, and exclusionary development experienced by the neighborhood before its demographics changed.

Safe cycling amenities are deeply associated with wealth and gentrification in Portland, despite the prominent culture of biking in marginalized populations. The association between biking infrastructure and class is so strong that some Portland communities call bike lanes "the White stripes of gentrification" (Mirk, 2009). This municipal neglect has dangerous consequences for the safety of nondrivers. For example, in Chicago, Black and Hispanic cyclists are more likely to suffer from fatal crashes. Researchers assert that this may be due to the lack of adequate biking infrastructure and safety measures in marginalized communities (Flanagen et al., 2016). 
This phenomenon is seen nation-wide, and is symptomatic of the greater issue of transportation injustice. Transportation investment and burdens are inequitably distributed throughout the urban landscape based on neighborhood demographics. Marginalized communities, like the Albina District, watch their neighborhood get split in half by highways or displaced by incoming transit infrastructure that hikes property values. People of color and lower-incomes disproportionately suffer transportation burdens, like pollution, excessive noise, and safety hazards, while seeing very limited investment in safe transportation infrastructure, like bike lanes, sidewalks, or traffic-slowing mechanisms in their neighborhoods (Flanagan et al., 2016; Aleck, 2017; Goodling et al., 2015).

A byproduct of an auto-centric urban landscape are 'heat islands' due to excessive concrete and asphalt and lack of vegetation in underserved neighborhoods. Pollution from traffic and highways threaten the health of surrounding residents. For example, the Jade District in East Portland, home to the largest concentration of Asian Americans in the city, is surrounded by major, traffic-congested transportation corridors on all sides with severely inadequate tree canopy, about half the coverage recommended by the US Forest Service. The district's autocentric planning exposes its community to toxic air emissions, causing asthma rates in the area to be twice that of the national average. The Jade District has patchy and inadequate sidewalks beside wide roads and speeding traffic, frequently causing car crashes and endangering pedestrians. The lack of tree canopy coupled with "park-deficiency" and ample concrete puts the district in the top $25 \%$ of vulnerability to the heat island effect (An \& Dubey, 2017).

Portland has long been celebrated for its bike-friendly streets, walkable neighborhoods and plentiful parks. This image serves the city's brand and ensures that it continues to absorb growing capital. Portland is one of the U.S.'s fastest gentrifying cities, with home values in 
gentrifying tracts increasing by 77.2\% from 2000 to 2017 (Maciag, 2015; Comen, 2019).

Meanwhile, districts like East Portland experience chronic neglect and disinvestment because they are not a lucrative option for neoliberal sustainability.

\section{PUBLIC-PRIVATE PARTNERSHIPS}

The inequitable distribution of Portland's sustainability brand is indicative of the neoliberal economic arrangements that strip city governments of their resources and push them to rely on public-private partnerships which predominantly serve elite stakeholders. These partnerships often contribute to urban sustainability's failure to provide social equity, because underserved populations don't promise high returns, unless those neighborhoods are gentrified.

Portland's urban renewal projects are operated by the Portland Development Commission (PDC), now known as Prosper Portland, a "quasi independent" development agency whose work in the city has been nothing if not controversial. Its organizational culture has been autocratic and profit-oriented since its foundation in 1958, when Mayor Terry Schrunk appointed businessman Ira Keller to govern the commission's activities (Gibson, 2004). Keller's first urban renewal project drastically altered 110 acres of urban landscape in South Portland, known as the South Auditorium district. The mass displacement of thousands of low-income and elderly residents and the dismantlement of a well-established Jewish and Italian enclave was justified because the city classified the area as blighted. Block after block of homes, small businesses, bars and restaurants were demolished. High rises and parks with fountains replaced old churches and synagogues. Modern architecture razed hundreds of old homes that dated back to the late $1880 \mathrm{~s}$ (Abbott, 2018; Killen, 2019). 
Proponents of the project praised it for bringing 15,000 new jobs, increased tax revenue, and post-modern design to the 'blighted' South Portland (Abbott, 2018). While it is true that much of the area was derelict, its renewal offered zero relief or benefit to those living in the previously underserved community. The PDC was criticized for lack of community participation and Keller's domineering attitude. This is a pattern in PDC projects, echoed in the development of the Memorial Coliseum and the Emanuel Legacy Hospital in the 1960s and 1970s, as I discussed above.

The agency revitalizes an underserved area by developing amenities and landmarks that rebrand the space as desirable, and operates with little accountability or genuine community input. Their projects are created for incoming, wealthier populations, and have consistently caused severe displacement. Anderson (2018) notes that the development agency, "has for the past thirty or forty years, bulldozed communities and built new things, then pretended that they aren't on the hook for gentrification, even as the Black population in Portland has been displaced because of some of these changes and policies" (paras. 35). The PDC often claimed to be acting on behalf of residents, while skirting the outcomes of their projects and effectively co-opting development as branding opportunities.

For example, in 2014, the agency came under fire after it proposed that a Trader Joe's grocery store move into a vacant lot on Martin Luther King Jr. Boulevard in the Albina District. The PDC claimed that the area was a food desert in need of a grocery store, without actually consulting with the incumbent community, who adamantly disagreed and opposed the market. The PDC stated that the land would have been worth less as affordable housing than as a commercial space. The agency sold the lot to Trader Joe's for \$2.4 million less than its appraised value in order to incentivize the company to buy. Opposition noted that by losing money to 
ensure that Trader Joe's, an organic, trendy grocery store, moved into the area, the PDC was stimulating further gentrification in the area without working to secure the well-being of those in the neighborhood (Sevenko, 2017).

Markets like Trader Joe's grocery stores, which lean into a sustainability brand and target a health and earth-conscious class, are proven to have significant impacts on surrounding property values. A 2019 report indicates that homes near a Trader Joe's saw a 51\% increase in value, while those close to Whole Foods saw a 41\% increase (ATTOM, 2019). It is useful for the PDC to sell land to Trader Joe's at such a massive discount, because the company would not only rebrand the area to target a desirable, sustainable class, but would also increase the value of the neighborhood, causing incumbent residents to be priced out to pave way for this incoming class. The new, higher tax base would secure a greater return on the PDC's investment.

After significant local backlash, particularly from Black residents, the plans collapsed and Trader Joe's backed out of the deal. In 2017, the agency changed its name to Prosper Portland, representing an effort to atone for its failures and move towards more inclusive development. Though it has made significant strides to develop more equitable projects, Prosper Portland's financing mechanisms still rely on neoliberal arrangements that serve private capital interests first (Sevenko, 2017; Prosper Portland, 2020).

Prosper Portland funds their projects with Tax Increment Financing (TIF), a tactic to garner capital for development in areas where the market forces are too weak (Prosper Portland, 2020). After the city designates an area as an urban growth boundary (URA), the properties within the boundaries are assessed and their values are 'frozen' at those rates before any renovation. The renewal district is then able to finance development projects by borrowing funds from future growth in property taxes. This borrowed capital pays for development projects, 
which stimulate further renewal and investment. As more and more capital is funneled into the area, the more the property values rise, causing the actual property taxes to rise as well. The portion of property taxes above the 'frozen' values is called the tax increment, and is used to pay off loans and reimburse the investors that contributed to the urban renewal projects (Cortright, 2019; Erickson, 2011; National Housing Conference, 2017).

Proponents of tax increment financing accurately indicate that this is one of the only means that municipalities can fund economic development and environmental remediation initiatives in poor neighborhoods without raising taxes. While its stated intention is to revitalize blighted communities, in practice TIF tends to sideline community development and concentrate more on economic development without concern for pre-existing residents. Cities have implemented TIF for two distinct purposes: to fund commercial development in middle- or upper-class neighborhoods, or to redevelop underserved communities and inject new wealth into the area via commercial and residential development. The process reflects cities' inability to properly improve disinvested neighborhoods due to lack of federal funding for redevelopment and social services. Residents in these areas are either unable to afford, or unwilling to pay higher property taxes that may replace these federal funding cuts. This leaves municipal governments with little choice but to increase the tax base as a whole by developing higherincome residential and commercial development on cheap land in low-income neighborhoods (Easterling, 2016; Erickson, 2011).

When TIF and URA planning lack a steady focus on affordable housing or a commitment to mitigating displacement, TIF becomes a vehicle for gentrification and the inverted quarantine. When an area is declared as blighted, like the Albina District, TIF is used to raze over lowincome neighborhoods. Instead of replacing these units with affordable housing or assuring that 
displaced residents are taken care of, the PDC/Prosper Portland uses TIF to construct middle- or upper-income housing, or commercial development. This reinforces the concentration of poverty in chronically underserved areas (Erickson, 2011).

Portland has made strides to curb the harmful impacts of TIF by adopting a Set Aside policy in 2006, which now dedicates around $40 \%$ of the TIF revenues to affordable housing. This policy still fails to generate spatialized equity, however, because redevelopment funded by TIF often still involves demolishing low-income housing in the name of "blight clearance." Once new affordable housing is constructed, it is in the context of rising property values in higherincome areas, causing the price-per-unit to increase and limiting the number of units that can be constructed. This means that families must pay higher rents for the housing that is still low quality (Cortright, 2019; Erickson, 2011).

Tax increment financing, and the reliance on public-private partnerships for the improvement of underserved neighborhoods points to the disempowered and underfunded condition of municipal governments under neoliberalism. The city doesn't have the capacity to adequately provide for all of its neighborhoods, and has to collect investments from private partners. This makes Portland's branding even more crucial as interurban competition is accentuated under neoliberalism. Public-private partnerships like TIF have been used for decades as economic mechanisms for urban development. New Market Tax Credits allow investors to invest in qualified, underutilized areas over seven years in exchange for a reduction in their federal income taxes. The Brownfields Incentives Program attracts private investment for brownfields redevelopment through fully-deductible environmental remediation costs in the same year incurred. The most recent public-private partnership program emerged in December 
2017, when President Trump created Federal Opportunity Zones under the Tax Cuts and Jobs Act (Carter, 2019).

Federal Opportunity Zones (FOZ) provide tax incentives for investors to funnel their realized capital gains towards qualified census tracts. Investors have 180 days to invest their profit into a 'Qualified Opportunity Fund,' which is any corporation or partnership that then directs $90 \%$ of that capital towards a project or business within the opportunity zone. In return, the investors can defer on their capital gains tax, and receive increasing tax deductions to the original investment the longer the investors hold their capital in the project. In order to receive the maximum tax cut, the investor must hold the investment for at least seven years. However, no matter what date the capital gains were invested, the investor must pay taxes on their original gains at the end of 2026 (Pamplin, 2020; Hauser \& Ordóñez, 2019; Fulton, 2019).

The nature of the FOZ program encourages investment in safe-bet projects that promise high return, which are not necessarily projects that need investments (Pamplin, 2020; Hauser \& Ordóñez, 2019; Fulton, 2019). It also incentivizes outside businesses and developers to relocate in these qualified, previously underserved areas in an effort to capture these investments. The relatively quick deployment of capital from its realization to the receiving project, and the 2026 deadline, undermine any substantial vetting process for the recipient projects that may ensure the funds are equitably distributed and benefitting the incumbent community. There is little regulation on what qualifies for investment. The policy states that a project or business must be within the qualified opportunity zone and must "substantially improve" the area. 'Substantial improvement' is currently defined as a rise in property values by an equal or greater amount than the initial investment (Carter, 2019). 
Investors seeking to gain the maximum tax deduction after seven years of investment, had to hastily invest before the end of 2019. They often selected 'market-ready' real estate projects that were already underway, because it was the most comfortable and secure decision made with such limited time. This pattern is exacerbated by a policy provision that allowed a quarter of the qualified opportunity zones to contain $125 \%$ of the area median income, if those zones are adjacent to census tracts containing the required baseline demographics of $20 \%$ poverty and/or $80 \%$ area median income. The provision essentially allows several areas that are already undergoing gentrification to qualify as an opportunity zone and receive even more investment. These outlying areas are the most attractive to investors because they promise the highest return (Carter, 2019).

When the FOZ program was introduced to Portland, alarm bells went off for many city officials. Prosper Portland, who would naturally assume the position of executing the program in the city, decided to remain hands off in hopes that they wouldn't take any heat for gentrification and increased inequity that was anticipated to follow the FOZ program. Instead, they educated neighborhood organizations about the program and allowed them to designate themselves as a recommended tract if they saw it fit. Due to past trauma from a history of gentrification and displacement, most underserved areas opted out as opportunity zones out of concern for the impact on their community. By contrast, nearly every neighborhood in the city's inner-core, where expensive waterfront property and sustainable redevelopment has already taken place, earned the designation as an opportunity zone (Pamplin, 2020; Carter, 2019).

New capital is being funneled to areas where plenty of capital already existed. Despite the obvious inequality and loud concerns over risks of gentrification caused by the designated FOZs, no plans exist yet to mitigate these externalities. While public policy to properly utilize 
these investments are moving slowly and reluctantly, public-private partnerships looking to serve private developers are marketing waterfront property and environmental amenities to outside companies. The designated tracts in Portland reflect the failure of this program to grow capital in otherwise unattractive areas for investment (Pamplin, 2020; Carter, 2019).

The FOZ program clearly prioritizes the investors and capital growth over the existing community. According to the policy language, projects that "substantially improve" the area don't necessarily improve residents' quality of life, but instead increase the area's property values. Rising property values is the main ingredient for displacement. A study released by Zillow revealed that property sales prices have increased by $20 \%$ in Opportunity Zones since April 2018. It also confirmed that a vast portion of the neighborhoods classified as opportunity zones were already undergoing capital expansion and rising property values before the FOZ program (Casey, 2019). The intention is not to uplift community livelihood, but to uplift the financial gains for investors by securing high-returns and tax cuts. Poor communities continue to be replaced with wealthy in-migrants, or ignored all together (Carter, 2019).

\section{CYCLICAL NEGLECT OF PORTLAND'S PERIPHERIES}

The failure of urban development programs in Portland is exacerbated by the city's sustainable, progressive image. Extreme spatial inequality is both justified and created by Portland's brand as an eco-conscious, progressive, creative city. Neighborhoods east of $82^{\text {nd }}$ Ave. are hardly recognizable as the supposedly green, liveable Portlandia. As the inner-core absorbs growing capital and development, the neglected periphery absorbs increasing poverty. The devaluation of East Portland allows urban blight and environmental burdens to accumulate 
outside of the inner-core's 'inverted quarantine,' ensuring that Portland's brand remains untarnished.

Portland's sustainability is spatialized. As central post-industrial spaces saw capital expansion under the banner of sustainability and community revitalization, East Portland saw 'piecemeal development' and the absorption of poverty, blight and displaced populations. East Portland's sprawling urban landscape, residual from post-war suburbia, paved the way for cheap in-fill development throughout the 1990s and early 2000s. The city anticipated infrastructural strain and initiated policies such as higher density zoning plans, to accommodate East Portland's expanding population. While this limited sprawl, it also concentrated poverty. Between 1996 and the mid-2000s, $40 \%$ of the city's new housing units were constructed in neighborhoods east of $82^{\text {nd }}$ Ave, the majority of which were low-cost, multi-family apartments. These city plans initially indicated that infrastructural improvements and environmental hazards in the area would be addressed with eventual upgrades, transit development, and environmental protections. However, despite early concerns from both policymakers and vocal community activists, East Portland is still waiting for equal infrastructure and development to the rest of the city (Goodling et al., 2015; Regional Equity Atlas, 2012).

Political negligence and developer indifference channel funds away from East Portland, even as it accrues growing poverty and environmental burdens. East Portland receives less spending from all municipal bureaus aside from police and fire, despite its neighborhoods ranking the lowest in all 'liveability' indicators, such as transit, access to green space, traffic deaths, safety, and walkability (Regional Equity Atlas, 2012). After the Obama Administration distributed federal stimulus funding for urban development in 2009 , only $.6 \%$ of the package was invested east of $82^{\text {nd }}$ Ave. Portland's mayor at the time claimed this was because East Portland 
lacked the "backend planning" for shovel-ready projects that would have qualified funding. Lack of adequate federal funding is a pattern in East Portland. Development projects in the district receive less than $10 \%$ of citywide federal stimulus annually (Mirk, 2010).

East Portland's urban landscape is marked by decaying, auto-centric infrastructure, sparse greenspace, and significantly higher rates of poverty and minority populations. Between 2000 and 2010, East Portland absorbed 44\% of the city's growing population and saw a $68 \%$ increase in its nonwhite population. During this same period, four out of the five census tracts that saw the most significant decline in income were located east of $82^{\text {nd }}$ Ave., while all six of the tracts that saw the greatest increase in income are west of $82^{\text {nd }}$ Ave. Two of these tracts are in the gentrified Albina District. Much of the displaced populations from the gentrified inner Portland have landed in East Portland (Goodling et al., 2015).

In 1970, before the gentrification of the Albina District, 70\% of Portland's inner North and Northeastern populations were African American. This was largely due to segregatory housing practices that barred Black residents from most other Portland neighborhoods. Over the proceeding 40 years, there has been a dispersal of these demographics throughout East Portland due to gentrification in lower Albina. Some of these census tracts lost over a third of its Black residents since 2000. Now, East Portland contains most of the city's diversity. In the 2010 census, 57\% of the East Portland population identified as people of color. This is in stark contrast to the $23 \%$ of non-White Portlanders in city-wide demographics. While Portland is ranked as the whitest major city in the U.S., East Portland is among the most racially diverse areas in the state of Oregon. (PBOT, 2012; Goodling et al., 2015; Bates et al., 2014). The economic deprivation and demographic composition of East Portland highlight the spatialized, and correspondingly racialized, limitations of Portland's sustainability brand. 
Low-income residents and people of color are concentrated in the devalued East Portland due in part to systemic hostility towards affordable housing in the rest of the city. The Federal Housing Authority requires that states and counties receiving housing funds for Section-8 vouchers $^{2}$, tax credits for affordable units, and federal block-grant funds must evenly distribute affordable housing to avoid segregation or concentrated poverty. Despite the tri-county Portland Metro (Multnomah, Clackamas, and Washington) receiving around \$170 million annually, most individuals relying on subsidized housing are systemically placed in East Portland. Census tracts in East Portland contain an abundance of affordable units, while wealthier tracts in the inner-core or the wealthier suburbs in the South and West barely have any affordable housing. Home Forward, Multnomah County's housing authority, increased the number of distributed Section-8 vouchers by almost 2,100 from 2001 to 2011 . Of these new vouchers, $93 \%$ of recipients were housed east of $82^{\text {nd }}$ Ave. African American renters were placed in these neighborhoods at much higher rates than White renters, causing the number of Black voucher-holders in East Portland to triple (PBOT, 2012; Schmidt, 2019; Goodling et al., 2105). In addition to East Portland's cheap and sprawling land, this absorption of poverty is due to municipalities' rejection of affordable housing units.

Several municipalities within the tri-county limits have denied affordable housing development, especially multi-family homes, within their districts. Many municipalities have evaded state requirements to construct multi-family housing by building upscale, higher-income multi-family units, or by allowing the construction of single-family homes on lots zoned for multi-family housing (Goodling et al., 2015). The predominantly White and affluent Lake

\footnotetext{
${ }^{2}$ Section-8 Vouchers cover a portion, or all, of the rent for specific units, and leave it up to the renter to find a landlord that will accept the voucher (Schmidt, 2019).
} 
Oswego and West Linn communities have just .1\% of the three counties' affordable units. In fact, these municipalities have nearly five times the number of multimillion-dollar homes than affordable rentals (Schmidt, 2019).

In the mid-1990s, Metro, Portland's government agency charged with overseeing regional land use, sought to mitigate the uneven affordable housing distribution by implementing a "fair share" policy. It threatened the imposition of inclusionary zoning regulations if the policies didn't spur an increase of affordable housing supply. This threat triggered a backlash from the suburbs and homebuilders, which led to a ban on inclusionary zoning across the state. Eventually, suburban municipalities pushed Metro to amend its charter in 2002 to prohibit the agency from increasing density requirements in neighborhoods zoned for single-family homes. This gutted the capacity of the city to enforce even and equitable distribution of affordable housing, and forced it to rely on weak, voluntary affordable housing measures in the region (Goodling et al., 2015) $)^{3}$.

Hostility towards affordable housing and low-income renters is the byproduct of prioritizing capital over community within a neoliberal system. Municipalities want to uphold a pristine image and clean environment that keep property values high and investment flowing. This reinforces the inverted quarantine and justifies exclusionary housing practices with profitability, despite their violation of the Fair Housing Act. Furthermore, the failure to evenly distribute affordable housing systemically isolates the poor communities, especially those of

\footnotetext{
${ }^{3}$ In 2017, the city successfully implemented an inclusionary zoning requirement for new residential buildings with over 20 units. Landlords are compelled to rent at least a fifth of their units for rates under their market value. This caused the percentage of permits for residential buildings with more than 20 units to drop 64\% over the subsequent two years. Rather than effectively growing the number of affordable housing units, this policy has diminished the housing stock across all incomes (The Editorial Board, 2020).
} 
color, living in the infrastructurally substandard and environmentally hazardous tracts in East Portland.

Around 20,000 households within the three Metro counties receive housing assistance. People of color are overrepresented in this group due to historical economic exclusion. In Portland's Multnomah County, one out of every five African American renters, equating to over 8,800 Black residents, depend on housing assistance (Schmidt, 2019). In both state and countyrun rental assistance programs, more than half of assisted African American and Latino renters were placed within census tracts of over $20 \%$ poverty, most of which are located in East Portland (Bates et al., 2014; Schmidt, 2019; Goodling et al., 2015). The unequal distribution of affordable housing prominently impacts Portland's populations of color, and exacerbates environmental racism and the inverted quarantine.

Portland's brand of sustainability, liveability, and progressive urbanism parallels its reputation of whiteness. This imaginary is upheld by the inner-core neighborhoods, where incomes are rising, diversity is declining, and green infrastructure and community-centered design is ample. These characteristics begin to fall away as one travels to the eastern margins of the city. East Portland would appear to a visitor as a completely different city, unrecognizable as the supposedly progressive, community-centered, sustainable city of Portland. Goodling et al. (2015) notes,

"East Portland neighborhoods differ markedly from those praised for their walkability west of $82^{\text {nd }}$ Avenue. The compact residential lots and quaint commercial districts that emerged along streetcar routes in the early part of the twentieth century-markers of 'liveability' that have earned Portland its laurels-are the norm in Portland's inner 
neighborhoods, but are markedly absent in the suburban neighborhoods east of $82^{\text {nd }}$ Avenue" (p. 6).

As more people are pushed out from the gentrifying neighborhoods to the west, East Portland's rates of poverty and diversity are growing as its population increases. East Portland contains the city's largest population and greatest amount of land, yet it still suffers municipal neglect.

Despite decades of tax revenues that should have funded improvements, East Portland continues to face inadequate infrastructure and sparse greenspace.

East Portland's devaluation is largely due to neoliberal economics, which forced the city to operate with meager federal funding and to rely instead on public-private partnerships that allow capitalist stakeholders to designate the distribution of investment. Portland's image seems to be more important than its people. Consequently, marginalized communities in the peripheries of the city where investments barely reach are perpetually neglected. 


\section{Conclusion}

Sustainable development in cities is not inherently negative or harmful. Green infrastructure can immensely benefit communities, especially those in close proximity to environmental hazards. Street trees and green spaces improve air quality and reduce risk of respiratory illnesses, while improving residents' mental and physical health. Studies indicate that an increase in parkland and trees can even decrease rates of crime. Biking infrastructure and sidewalks diminish auto-centricity, protect nondrivers from car accidents, and reduce harmful auto emissions. These amenities also decrease the dangers of heat islands and increase carbon sequestration. Sustainable development significantly improves the physical, mental, and social health of the surrounding community, and is a crucial feature for contemporary cities. However, when these features are tethered to neoliberal agendas and profiteering actors, environmental and community health is sidelined (An \& Dubey, 2017; Willamette Partnership, 2019).

Luxury apartments and commercial amenities are prioritized before the public parks and environmental amenities that were promised in initial plans. The communities in most need of green infrastructure, who suffer from pollution, heat islands, and social fragmentation, are neglected or displaced by sustainable development. Despite its banner of uplifting virtues, sustainable development fails and becomes harmful when it operates under the hand of neoliberalism and prioritizes a capitalist agenda.

Portland was one of the pioneers of urban sustainability, but it did not escape the exploitative and destructive nature of neoliberalism. The city resorts to public-private partnerships to finance development projects that ultimately serve powerful stakeholders more than existing residents. Investors reap higher returns from funneling money into spaces like the 
waterfront districts or lower Albina, where capital expansion has already transformed postindustrial land into lucrative commercial or residential property. In underserved areas with cheap land that is deemed lucrative, developers inject value with projects that attract and serve higherincome populations, rather than the incumbent communities. This takes advantage of the lowcost land and unempowered populations, and gentrifies the area. The city benefits from this process when existing low-income populations are replaced by higher income residents who increase the area's tax base.

Municipal governments rely on taxes and private investment for large scale development projects due to a neoliberal economic order that undermines the role of the public sector. Neoliberalism strips federal funding for local governments, leaving them no choice but to find new avenues through the private sector and wealthy taxpayers to finance urban development. This is why Prosper Portland, or the PDC finances their development projects with tax increment financing, and why for so long these projects have disenfranchised communities of color or lower incomes. The land that these populations typically occupy offers the opportunity for lowcost development with little push-back due to residents' lack of political power. Public-private partnerships are able to cheaply construct new commercial, environmental, or residential amenities tailored for a higher paying consumer. This process promises high return for investors, and benefits the city by reinforcing its brand.

The transformation of the post-industrial waterfront or the Albina District reflects this process. Portland's sustainability brand was reaffirmed by the newly injected environmental amenities and creative economies. Incoming populations engage with these new economies, either as tourists or new residents, and solidify this brand as a reality. However, it becomes clear after travelling to the margins of the city that this is a reductionist, utopian image of Portland. 
The pollution and poverty that once defined these now iconic spaces was simply exported east of $82^{\text {nd }}$ Ave.

East Portland has absorbed the features of the city that don't fit in with Portland's brand. The district is the largest in the city with the highest population, but it receives the least amount of funding from nearly all government bureaus aside from fire and police. Poverty and diversity is concentrated in East Portland at rising rates, while the gentrifying inner-core sees increasing average incomes and decreasing diversity. East Portland suffers from municipal neglect that has denied the area of equitable infrastructure. The auto-centric urban landscape and lack of green space leaves the district vulnerable to the heat island effect and traffic-related deaths or injuries. It has inadequate biking and pedestrian infrastructure, despite Portland's proud reputation as one of the nation's most bike-friendly cities. East Portland sheds light on the massive failure of urban sustainable development to uplift the environmental health, economic prosperity, and social equity of cities. The city of Portland has made a concerted effort to establish itself as a sustainable global city, and for many residents and visitors, its green amenities do improve the quality of life. But for the 160,000 plus residents in East Portland, these amenities are not visible or accessible.

The lack of investment in East Portland speaks to neoliberalism's prioritization of capital over people. East Portland is not a secure investment, and doesn't immediately serve stakeholders, or the Portland brand. It is tucked away in the urban peripheral, out of sight, out of mind. Portland's branding has become increasingly pertinent to the city's status as climate change, and environmentalism continues to shape popular values. The rise of sustainability to the forefront of public conscience has prompted consumer goods and global cities alike to market themselves as eco-friendly. The domain of sustainable urbanism that Portland once dominated is 
now crowded with countless other cities that all tout environmental development and progressive policies. Portland's new competition has made its branding all the more significant.

If cities like Portland want to uphold their sustainable values and meaningfully impact the health of their communities and environments, sustainable development must be decoupled from profit and capitalist logic. Communities must be powerful and determinant voices in planning processes, and developers must be transparent. The PDC was criticized for its lack of transparency and genuine community engagement. The public forums and events created a façade of civic participation, but ultimately most decisions were made behind closed doors, and the outcome rarely matched the communities' plans. This form of citizen involvement does not prioritize community needs. It is meant to placate the public, rather than provide meaningful opportunity for partnership and contribution.

"If the goal of sustainability is to improve the quality of life for residents while producing rewarding livelihoods and maintaining a healthy and clean environment, residents must participate in, agree to, and benefit from development plans" (Gould \& Lewis, 2017, p.4). This form of 'bottom-up sustainability' needs to be driven by, and developed for, existing community members, and should uphold an indispensable goal of uplifting marginalized and underserved populations. Anti-racist and anti-displacement intentions should remain a priority throughout the entire process, from ideation to completion. In order for the community to be an effective force, it must be educated and connected.

Gould and Lewis (2017) stress community organization. They assert that organized communities are more likely to receive information early-on about development plans, and are more able to contest harmful plans and assert their demands. Communities are also more powerful if they hold alliances and relationships with local officials. They have access to more 
information and their voice is elevated. Strengthening community capacity should also be a priority for improving urban sustainable development. Residents must be educated and informed in order to grow their confidence and capability in planning politics. This is extremely important for communities of color and low-income residents because these groups are historically excluded from political and economic power. Lack of experience can discourage them from engaging in bureaucratic, political planning processes (Gould \& Lewis, 2017; Gibson, 2007).

Additionally, transparency on the part of developers and agencies is crucial for social equity in sustainable development. Community members must be able to hold local governments and corporations accountable for development (Gould \& Lewis, 2017; Gibson 2007). The PDC was condemned for its lack of transparency when it failed to disclose the details of tax increment financing to the public. In 2014, after the PDC sold a vacant lot on MLK to Trader Joe's for a steep discount, the executive director of the nonprofit Portland Community Reinvestment Initiative outlined four demands for the agency, which included the full tax increment financing records from urban renewal areas, and all funding receipts with names and amounts of investments (Silvis, 2014). Transparency is paramount when sustainable development functions within a neoliberal, capitalist system, because it deters concession to large corporations and encourages community-centered development.

Carter (2019) agrees that transparency is indispensable for curbing gentrification during development driven by public-private partnerships or tax incentives, like Federal Opportunity Zones (FOZ). He also names community relationships, the preservation of public spaces like parks, schools, community centers, and libraries, and the construction and protection of affordable housing as crucial for mitigating displacement. Gould and Lewis (2017) suggest that sequency during development must intentionally prioritize people of color and lower incomes. 
Affordable housing and anti-displacement policies and programs must be installed and secured before any luxury construction can begin. Development to benefit the existing community must come before any development targeted at outside populations.

Equitably distributed sustainable development in cities is essential for the livelihoods of urban communities and the preservation of urban environments. Green infrastructure and policy is indispensable as climate change intensifies and global populations continue to increase and urbanize. Untangling sustainability from neoliberal capitalism is increasingly important. If the majority of the population stays isolated from the environmental amenities and benefits enjoyed inside the inverted quarantine, they will reject environmental protection and policy (Gould \& Lewis, 2017). The pillar of social equity must stay intact in order for sustainable development to meaningfully impact change.

Future research and work in the urban sustainable development field should focus on community involvement throughout the planning and execution processes. It should examine which displacement relief efforts have succeeded, and which have failed. If I had time to write a book on this topic, I would dive deep into the economic mechanisms through which sustainable development is financed. Greater knowledge of these processes is useful for dissecting the neoliberal operations that support private influence in public development projects. I would also examine more specific cases of sustainable development in Portland. My research would additionally benefit from exploring successful sustainable development projects that didn't cause displacement in order to inform how we can improve.

Equitably distributed green infrastructure holds immense potential to uplift the quality of life and land around the globe. Urban sustainable development in our cities is fruitful if we are able to disentangle social and environmental enhancement from the grip of neoliberalism. Clean 
air and land cannot be tied to profit. When capital growth takes the reigns of sustainability, green development is greenwashed, and vulnerable communities suffer. 


\section{Works Cited:}

Abbott, C. (2018, March 17). South Portland/South Auditorium Urban Renewal Project. Oregon Encyclopedia.

https://www.oregonencyclopedia.org/articles/south_portland_south_auditorium_urban_renewal_p roject/

Ackerman, L. (2016, March 16). ALBINA, PORTLAND, OREGON (1870- ). Black Past. https://www.blackpast.org/african-american-history/albina-portland-1870/

An, C., \& Dubey, S. (2017). Greening the Jade: An Economic Analysis of the Costs and Benefits of Urban Greening in SE Portland (pp. 1-27, Rep.). Portland, OR: Ecotrust.

Aleck, J. (2017, June 7). Displacement of Black Portlanders began long ago. KOIN.com. https://www.koin.com/news/displacement-of-black-portlanders-began-long-ago/870080775/

Anderson, D. (2018, April 27). Albina Rising: A group in Portland is working to undo the harm of urban renewal and heal the wounds of a community. Oregon Hummanities. https://www.oregonhumanities.org/rll/magazine/owe-spring-2018/albina-rising-deonna-anderson/

ATTOM Staff. (2019, July 31) New ATTOM Data Solutions Analysis Examines the Grocery Store Impact on the U.S. Housing Market. ATTOM Data Solutions. Retrieved October 19, 2020 from https://www.attomdata.com/news/market-trends/attom-data-solutions-2019-grocery-store-battle/

Bates, L., Curry-Stevens, A. \& Coalition of Communities of Color (2014). The African-American Community in Multnomah County: An Unsettling Profile. Portland, OR: Portland State University.

Bergman, M. M. (2019, March 8). 'They chose us because we were rural and poor': when environmental racism and climate change collide. The Guardian.

https://www.theguardian.com/environment/2019/mar/08/climate-changed-racism-environmentsouth

Bienkowski, B. (2016, January 14). Toxic Coal Ash Hits Poor and Minority Communities Hardest. Scientific American. https://www.scientificamerican.com/article/toxic-coal-ash-hits-poor-andminority-communities-hardest/

Billings, D. R. (2018). White Space, Black Space: Community Gardens in Portland, Oregon (Doctoral dissertation, Portland State University, 2018) (pp. 1-105). Portland, OR: Dissertations and Theses.

Carter, M. (2019). Federal Opportunity Zones: The newest gentrification tool? [Master's thesis, Georgia Institute of Technology] School of City and Regional Planning Applied Research Papers.

Casey, A. (2019, March 18). Sale prices surge in neighborhoods with new tax break. Zillow. https://www.zillow.com/research/prices-surge-opportunity-zones-23393/

Commission For Racial Justice. (1987). Toxic Wastes and Race in the United States: A National Report on the Racial and Socio-Economic Characteristics of Communities with Hazardous Waste Sites. New York, NY: United Church of Christ.

Cortright, J. (2019). A solution for displacement: TIF for affordable housing. City Commentary. https://cityobservatory.org/a-solution-for-displacement-tif-for-affordablehousing/\#: : :text=In\%202006\%2C\%20the\%20Portland\%20City,below $\% 2080 \% 25 \% 20$ median $\% 2$ 0family\%20income

Checker, M. (2011). Wiped Out by the "Greenwave": Environmental Gentrification and the Paradoxical Politics of Urban Sustainability. City \& Society, 23(2), 210-229. doi:10.1111/j.1548744x.2011.01063.x

Checker, M., McDonogh, G., \& Isenhour, C. (2015). Urban Sustainability as Myth and Practice. In C. Isenhour, G. McDonogh, \& M. Checker (Eds.), Sustainability in the Global City: Myth and Practice (New Directions in Sustainability and Society, pp. 1-26). Cambridge: Cambridge University Press. doi:10.1017/CBO9781139923316.001 
Comen, E. (2019, September, 25). Cities where neighborhoods are gentrifying the fastest. 24/7 Wall St. https://247wallst.com/special-report/2019/09/25/cities-where-neighborhoods-are-gentrifying-thefastest $/ 3 /$

Damewood, A. (2015, September 17). Is Portland's mayor green enough for Portland? Politico Magazine. https://www.politico.com/magazine/story/2015/09/portland-mayor-environmentalism-213158

Easterling, H. M. (2016). Gentrification and financial policy: tax increment financing and the implications for low-income residents. [Unpublished thesis]. The Pennsylvania State University Schreyer Honors College.

Erickson, K. (2011). Protecting low income residents during tax increment financing development. Washington Journal of Law \& Policy 36, 203-232. https://openscholarship.wustl.edu/law_journal_law_policy/vol36/iss 1/9

Flanagan, E., Lachapelle, U., \& El-Geneidy, A. (2016). Riding tandem: Does cycling infrastructure investment mirror gentrification and privilege in Portland, OR and Chicago, IL? Research in Transportation Economics, 60, 14-24.

Fulton, W. (2019, February 20). Opportunity zones: Gentrification on steroids? Rice Kinder Institute for Urban Research. https://kinder.rice.edu/urbanedge/2019/02/20/opportunity-zones-gentrificationsteroids\#: :text $=$ The $\% 20$ Opportunity $\% 20$ Zone $\% 20$ program $\% 20$ is,gentrification $\% 2 \mathrm{C} \% 20$ especia 11 \% $\% 20$ inside $\% 20$ the\%20Loop.

Gibson, K. J. (2007). Bleeding Albina: A History of Community Disinvestment, 19402000. Transforming Anthropology, 15(1), 3-25. doi:10.1525/tran.2007.15.1.03

Gibson, K. J. (2004). Urban Redevelopment in Portland: Making the City Livable for Everyone? In C. Ozawa (Ed.), The Portland Edge: Challenges and Successes in Growing Communities (pp. 6183). Island Press.

Goodling, E., Green, J., \& Mcclintock, N. (2015). Uneven development of the sustainable city: Shifting capital in Portland, Oregon. Urban Geography, 36(4), 504-527. doi:10.1080/02723638.2015.1010791

Gould, K., \& Lewis, T. L. (2017). Green gentrification : Urban sustainability and the struggle for environmental justice (Routledge, equity, justice, and the sustainable city series). Abingdon, Oxon ; New York, NY: Routledge.

Habitat for Humanity. (2020, June 26). The early history of Portland's racist housing strategies: Part one. Habitat for Humanity: Portland/Metro East. https://habitatportlandmetro.org/the-early-history-ofportlands-racist-housing-strategies-part-one/

Hagerman, C. (2007). Shaping neighborhoods and nature: Urban political ecologies of urban waterfront transformations in Portland, Oregon. Cities, 24(4), 285-297.

Hauser, D., \& Ordóñez, J. C. (2019, April 1). 4 ways “Opportunity Zones” squelch real opportunity. Oregon Center for Public Policy. https://www.ocpp.org/2019/04/01/opportunity-zones-oregonwasteful/

Hurley, A. J. (1995). Class, race and the shaping of the urban landscape. In Environmental Inequalities: Class, Race, and Industrial Pollution in Gary, Indiana, 1945-1980 (pp. 1-15). University of North Carolina Press.

Hwang, D. (2014, February 26). Jade District. https://www.apano.org/blog/2014/02/26/jade-district/

Killen, J. (2019, January 9). Throwback Thursday: 60 years ago, Portland began urban renewal plan for South Auditorium district. The Oregonian. https://www.oregonlive.com/history/2015/02/throwback thursday_60 years_ag.html

Krough, D. (2019, November 1). PDX demographics and rankings. The Southeast Examiner. https://www.southeastexaminer.com/2019/11/pdx-demographics-and-rankings/

Lavelle, M., \& Coyle, M. (1992). Unequal Protection: The Racial Divide in Environmental Law, A Special Investigation. The National Law Journal, 15(3).

Lee, T. (2015, June 15). Cancer Alley: Big Industry, Big Problems. MSNBC. http://www.msnbc.com/interactives/geography-of-poverty/se.html 
M. (2017, June 26). What are the boundaries of the Jade District? Jade District. http://jadedistrict.org/what-are-the-boundaries-of-the-jade-district/

Maciag, M. (2015, February). Gentrification in America Report. Governing: The Future of States and Localities. https://www.governing.com/gov-data/census/gentrification-in-cities-governingreport.html

Mirk, S. (2009, November 19). Bicycle race: Nonprofit investigates the Portland bike scene's racial gap. Portland Mercury. https://www.portlandmercury.com/portland/bicyclerace/Content?oid $=1854486$

Mirk, S. (2010, April 22). East of Eden. Portland Mercury. https://www.portlandmercury.com/portland/east-of- eden/Content?oid=2462525

Newkirk II, V. R. (2018, February 28). Environmental Racism is Real, According to Trump's EPA. https://www.theatlantic.com/politics/archive/2018/02/the-trump-administration-finds-thatenvironmental-racism-is-real/554315/

National Housing Conference. (2017, September 5). Tax Increment Financing: The Basics. https://nhc.org/policy-guide/tax-increment-financing-the-basics/

Pamplin Media Group. (2020, February 20). 'Opportunity Zones' a giveaway to wealthy investors. The Newberg Graphic. https://pamplinmedia.com/nbg/143-opinion/453068-369073-opportunityzones-a-giveaway-to-wealthy-investors

Portland Bureau of Transportation (PBOT). (2012). East Portland in motion: Apendix A. East Portland demographic overview. https://www.portlandoregon.gov/transportation/article/372607

Prosper Portland. (2020, March 13). About us. https://prosperportland.us/about-us/

Rawlins, A. (2014, October 7). Is your city the next Portlandia? CNN. https://money.cnn.com/2014/10/07/smallbusiness/portland-export-kashiwanoha/index.html

Regional Equity Atlas (2012). Maps and Analysis. Retrieved October 23, 2020, from http://www.equityatlas.org/maps-analysis

Silvis, H. (2014, February 3). PAALF responds to Trader Joe's pullout. The Skanner. https://www.theskanner.com/news/northwest/20815-paalf-responds-to-trader-joe-s-pullout

Smith, D. M. (2012, November 2). Breaking: Portland sustainability chief admits 'Portlandia' isn't really a parody. Grist. https://grist.org/cities/breaking-portland-sustainability-chief-admitsportlandia-isnt-really-a-parody/

Stroud, E. (1999). Troubled Waters in Ecotopia: Environmental Racism in Portland, Oregon. Radical History Review, 1999(74), 65-95.

Schmidt, B. (2019, January 10). Failure to support Fair Housing Act leads to subsidized segregation: Locked Out, Part 1. The Oregonian. Retrieved October 27, 2020, from oregonlive.com/portland/2012/06/subsidizing_segregation_locked.html

Sevcenko, M. (2017, May 18). Development agency becomes Prosper Portland. The Skanner. https://www.theskanner.com/news/northwest/25425-development-agency-becomes-prosperportland

TED. (2013, October 14). Jeff Speck: The walkable city [Video]. YouTube. https://www.youtube.com/watch? $\mathrm{v}=$ Wai4ub90stQ\&ab_channel=TED

The Editorial Board. (2020, January 5). The Housing Shortage in Profile: Construction in Oregon dropped to the lowest level since World War II. The Wall Street Journal. https://www.wsj.com/articles/the-housing-shortage-in-profile-11578263733?st=tnziraq7uuhv6p4

Vanolo, A. (2017). City branding: The ghostly politics of representation in globalising cities. New York ; London: Routledge.

Willamette Partnership. (2019). The Health, Air, and Water Benefits of Greening the Jade District. Portland, OR: Asian Pacific American Network of Oregon.

World Commission on Environment and Development. (1987). Our common future. Oxford: Oxford University Press. 